International Journal of Environmental Research and

Public Health

ISSN 1660-4601

www.mdpi.com/journal/ijerph

Article

\title{
Characterization of a Bioflocculant Produced by a Consortium of Halomonas sp. Okoh and Micrococcus sp. Leo
}

\author{
Kunle Okaiyeto *, Uchechukwu U. Nwodo, Leonard V. Mabinya and Anthony I. Okoh \\ Applied and Environmental Microbiology Research Group (AEMREG), Department of Biochemistry \\ and Microbiology, University of Fort Hare, Alice 5700, South Africa; \\ E-Mails: UNwodo@ufh.ac.za (U.U.N.); LMabinya@ufh.ac.za (L.V.M.);AOkoh@ufh.ac.za (A.I.O.) \\ * Author to whom correspondence should be addressed; E-Mail: okaiyetofranciskunle@yahoo.ca; \\ Tel.: +27-710-358-873; Fax: +27-866-286-824.
}

Received: 2 August 2013; in revised form: 25 September 2013 / Accepted: 1 October 2013 /

Published: 16 October 2013

\begin{abstract}
The physicochemical and flocculating properties of a bioflocculant produced by a bacterial consortium composed of Halomonas sp. Okoh and Micrococcus sp. Leo were investigated. The purified bioflocculant was cation and $\mathrm{pH}$ dependent, and optimally flocculated kaolin clay suspension at a dosage of $0.1 \mathrm{mg} / \mathrm{mL}$. The flocculating activity of the bioflocculant was stimulated in the presence of $\mathrm{Ca}^{2+}, \mathrm{Mn}^{2+}, \mathrm{Al}^{3+}$ and had a wide $\mathrm{pH}$ range of $2-10$, with the highest flocculating activity of $86 \%$ at $\mathrm{pH} 8$. The bioflocculant was thermostable and retained more than $70 \%$ of its flocculating activity after being heated at $80{ }^{\circ} \mathrm{C}$ for $30 \mathrm{~min}$. Thermogravimetric analyses revealed a partial thermal decomposition of the biofloculant at $400{ }^{\circ} \mathrm{C}$. The infrared spectrum showed the presence of hydroxyl, carboxyl and amino moieties as functional groups. The bioflocculant produced by the bacterial consortium appears to hold promising alternative to inorganic and synthetic organic flocculants that are widely used in wastewater treatment.
\end{abstract}

Keywords: bioflocculant; flocculating activity; consortium; Halomonas sp. Okoh; Micrococcus sp. Leo 


\section{Introduction}

Flocculants are widely used in various industrial processes such as drinking water treatment, downstream processes, wastewater treatment plants, and in different fermentation processes [1]. Although chemical flocculants have numerous advantages of being effective in terms of flocculating efficiency, affordability and availability, their usage has been reported to be harmful to humans [2]. In addition, they have been reported to be neurotoxic, carcinogenic and recalcitrant to degradation, thus constituting environmental nuisances [3]. Due to the adverse nature of chemical synthetic flocculants, more attention has been given to the use of flocculants produced by microorganisms [4].

Xia et al. [5] reported that the biopolymers produced by microorganisms during their growth are harmless, degradable, and do not lead to secondary pollution. As a result, bioflocculants are being considered as a good replacement for chemical flocculants used in wastewater treatment and other industrial processes [6].

In recent years, many studies have been undertaken where different microorganisms such as algae, fungi, bacteria and actinomycetes have been used in bioflocculant production [5,7]. Although many bioflocculants have been produced by different microbes, low flocculating activity and high production costs have been limiting factors hindering large-scale production [8].

According to the findings of Xia et al. [5], screening for microorganisms with high bioflocculant-producing capability and high flocculating efficiency is vital for success in this field. Furthermore, Fujita et al. [9] investigated the use of low-cost substrates in growth media for bioflocculant production as a possible cost-cutting measure. Some low-cost substrates such as soybean juice, fishmeal wastewater have been documented as alternative nitrogen source components in production media $[10,11]$.

The idea of using two or more microbes in consortium for bioflocculant production was first reported by Ma et al. [12]. The concept behind this approach was to improve the yield and flocculating efficiency of the bioflocculant produced by individual strains. Furthermore, Zhu et al. [13] reported that a compound bioflocculant produced by a mixed culture of strains Rhizobium radiobacter F2 and Bacillus shaeicus F6 had higher flocculating activity when compared to individual strains. In addition, Wang et al. [14] reported that the compound bioflocculant produced by a mixed culture of Rhizobium radiobacter F2 and Bacillus shaeicus F6 possessed higher flocculating efficiency than those from individual strains.

There is a dearth of information on bioflocculant production by bacterial mixed culture hence, Halomonas sp. Okoh and Micrococcus sp. Leo isolated from sediment samples of Algoa Bay of the Eastern Cape Province of South Africa, which in our previous studies had demonstrated good potential for the production of bioflocculants as axenic cultures, were investigated as a mixed culture for enhanced bioflocculant yields and the bioflocculant was characterized.

\section{Experimental Section}

\subsection{Source of Bacteria}

The bacteria was isolated from the sediment of Algoa Bay in the Eastern Cape Province of South Africa and maintained in $20 \%$ glycerol at $-80{ }^{\circ} \mathrm{C}$ as part of the culture collections of the Applied 
and Environmental Microbiology Research Group (AEMREG), University of Fort Hare, Alice, South Africa.

\subsection{Growth Media}

The growth medium for bioflocculant production was composed of glucose $(20 \mathrm{~g}), \mathrm{MgSO}_{4} \cdot 7 \mathrm{H}_{2} \mathrm{O}$ $(0.2 \mathrm{~g}),\left(\mathrm{NH}_{4}\right)_{2} \mathrm{SO}_{4}(0.2 \mathrm{~g}), \mathrm{K}_{2} \mathrm{HPO}_{4}(5 \mathrm{~g})$, urea $(0.5 \mathrm{~g})$, yeast extract $(0.5 \mathrm{~g})$ and $\mathrm{KH}_{2} \mathrm{PO}_{4}(2 \mathrm{~g})$ in a litre of filtered seawater at $\mathrm{pH} 6.5$ and sterilized by autoclaving at $121-124{ }^{\circ} \mathrm{C}$ for $15 \mathrm{~min}$ [15].

\subsection{Evaluation of Bioflocculant Production}

The bacteria were inoculated into a $250 \mathrm{~mL}$ flask containing $50 \mathrm{~mL}$ of production medium prepared according to description of Zhang et al. [15] and incubated at $28^{\circ} \mathrm{C}$ in a shaker at $160 \mathrm{rpm}$ for 5 days and centrifuged at $4,000 \times \mathrm{g}$ for $30 \mathrm{~min}$ at $4{ }^{\circ} \mathrm{C}$. The cell free culture supernatants were used to determine flocculating activities of the bioflocculant produced by the consortium.

\subsection{Determination of Flocculating Activity}

Using the description of Kurane et al. [16] with minor modifications, kaolin clay was used as the test material for determining the flocculating activity of the produced bioflocculant. Four grams of kaolin clay was suspended in $1 \mathrm{~L}$ of distilled water to make a concentration $(4 \mathrm{~g} / \mathrm{L})$. One hundred millilitres of kaolin suspension was measured into $250 \mathrm{~mL}$ flask, $3 \mathrm{~mL}$ of $1 \% \mathrm{w} / \mathrm{v} \mathrm{CaCl}_{2}$ and added $2 \mathrm{~mL}$ of culture supernatant were added. The mixture was agitated vigorously for $60 \mathrm{~s}$ and then poured into $100 \mathrm{~mL}$ measuring cylinder and allowed to sediment for $5 \mathrm{~min}$ at room temperature. The optical density (OD) of the clarifying supernatant was measured at $550 \mathrm{~nm}$ with a UV spectrophotometer (Thermo Spectronic, USA) and the flocculating activity determined as follows:

$$
[(\mathrm{A}-\mathrm{B} / \mathrm{A})] \times 100 \%
$$

where A and B are optical densities of control and sample measured at $550 \mathrm{~nm}$ respectively.

\subsection{Time Course Assay for Bioflocculant Production}

The optimum culture conditions and cultivation conditions previously described for the individual strains were used. The strains were pre-cultured in $50 \mathrm{~mL}$ growth medium contained in $250 \mathrm{~mL}$ flask on the rotary shaker $(160 \mathrm{rpm})$ at $28{ }^{\circ} \mathrm{C}$ for inoculation preparation. After $18 \mathrm{~h}$ of cultivation, $2 \%(\mathrm{v} / \mathrm{v})$ culture broth of Halomonas sp. Okoh and 4\% (v/v) culture broth of Micrococcus sp. Leo were inoculated into $200 \mathrm{~mL}$ of the production medium in $500 \mathrm{~mL}$ flask [14]. Batch fermentation was carried out under the same cultivation conditions as those for pre-cultivation. Medium samples $(15 \mathrm{~mL})$ were withdrawn at $12 \mathrm{~h}$ intervals and monitored for $\mathrm{pH}$, cell growth, cell count and flocculating activity. Two millilitres of culture broth was centrifuged at $4,000 \times \mathrm{g}$, at $4{ }^{\circ} \mathrm{C}$ for $30 \mathrm{~min}$, and the cell free supernatant was used as the test bioflocculant to determine the flocculating activity. The bacterial growth was monitored by measuring the optical density $\left(\mathrm{OD}_{600}\right)$ and bacterial counts was determined by standard spread plate technique using nutrient agar and all plates were incubated at $35{ }^{\circ} \mathrm{C}$ for $36 \mathrm{~h}$. 


\subsection{Extraction and Purification of the Bioflocculant}

After 5 days of fermentation, the culture broth was centrifuged at $4,000 \times \mathrm{g}$ at $4{ }^{\circ} \mathrm{C}$ for $30 \mathrm{~min}$. In order to remove the insoluble substances, one volume of distilled water was added to the supernatant phase and then centrifuged at $4,000 \times \mathrm{g}$ for $15 \mathrm{~min}, 4{ }^{\circ} \mathrm{C}$. Two volumes of ethanol were added to the supernatant, and the solution was agitated then left standing at $4{ }^{\circ} \mathrm{C}$ for $12 \mathrm{~h}$. The precipitate was vacuum-dried and then re-dissolved in distilled water $(1 \% \mathrm{w} / \mathrm{v})$ and one volume of a mixture of chloroform and $n$-butyl alcohol $(5: 2 \mathrm{v} / \mathrm{v})$ was added. After agitating, the mixture was left standing at room temperature for $12 \mathrm{~h}$. The supernatant was then be centrifuged at $4,000 \times \mathrm{g}$ for $15 \mathrm{~min}$ at $4{ }^{\circ} \mathrm{C}$ and dialyzed overnight against distilled water overnight. The dialysate was then vacuum-dried in order to obtain a purified bioflocculant.

\subsection{Determination of Bioflocculant Dosage (Jar Test)}

Different concentrations of the bioflocculant solution $(0.02,0.04,0.06,0.08,0.1,0.2,0.3,0.4$ and $0.5 \mathrm{mg} / \mathrm{mL}$ ) were prepared and their flocculating activities evaluated. Four grams of kaolin clay was weighed and dissolved in $1 \mathrm{~L}$ of distilled water. Three millilitres of $1 \%(\mathrm{w} / \mathrm{v}) \mathrm{CaCl}_{2}$ and $2 \mathrm{~mL}$ of bioflocculant solution were both added to $100 \mathrm{~mL}$ kaolin suspension in $500 \mathrm{~mL}$ beakers. The solution was agitated at $200 \mathrm{rpm}$ for $3 \mathrm{~min}$ and the speed reduced to $45 \mathrm{rpm}$ for further $10 \mathrm{~min}$ of agitation [17]. The solution was poured into $100 \mathrm{~mL}$ measuring cylinder, allowed to sediment for $10 \mathrm{~min}$ and $2 \mathrm{~mL}$ of clear supernatant withdrawn and the flocculating activity was read at $550 \mathrm{~nm}$.

\subsection{Effect of Cations on Flocculating Activity of Purified Bioflocculant}

A solution of bioflocculant concentration $0.1 \mathrm{mg} / \mathrm{mL}$ was prepared. The effects of the following salt solutions at $1 \% \mathrm{w} / \mathrm{v} \mathrm{NaCl}, \mathrm{KCl}, \mathrm{LiCl}_{2}, \mathrm{MgCl}_{2}, \mathrm{MnCl}_{2} \cdot 4 \mathrm{H}_{2} \mathrm{O}, \mathrm{BaCl}_{2}, \mathrm{AlCl}_{3}$ and $\mathrm{FeCl}_{3} \cdot 6 \mathrm{H}_{2} \mathrm{O}$ on flocculating activity of the purified bioflocculant were determined according to Kurane et al. [16].

\subsection{Effect of pH on Flocculating Activity of Purified Biofloculant}

Concentration of $0.1 \mathrm{mg} / \mathrm{mL}$ solution of bioflocculant solution was prepared. The adjusted $\mathrm{pH}$ of individual kaolin solutions in separate flasks ranged from 2-12 prior to determining flocculating activity at each of these $\mathrm{pH}$ values [18].

\subsection{Effect of Temperature on Flocculating Activity of Purified Bioflocculant}

The purified bioflocculant was dissolved in distilled water to give a concentration $0.1 \mathrm{mg} / \mathrm{mL}$. Ten millilitres of the bioflocculant solution was heated at $50{ }^{\circ} \mathrm{C}, 60^{\circ} \mathrm{C}, 70{ }^{\circ} \mathrm{C}$ and $80{ }^{\circ} \mathrm{C}$ for $30 \mathrm{~min}$, and then the temperature dependence was determined by measuring the residual flocculating activity for kaolin suspension (4 g/L) at room temperature [14]. 


\subsection{Fourier Transform Infrared Spectroscopy (FTIR)}

The functional groups of the bioflocculant were determined using a Fourier transform infrared (FTIR) spectroscopy (Perkin Elmer System 2000, Cambridge, England). The bioflocculant was ground with $\mathrm{KBr}$ salt at $25{ }^{\circ} \mathrm{C}$ and pressed into a pellet for FTIR analysis over a wave number range of 4,000 to $350 \mathrm{~cm}^{-1}$ [19].

\subsection{Thermo-Gravimetric Analysis (TGA)}

Ten milligrams of the bioflocculant was analysed by TGA analyzer (STA 449/C Jupiter, Netzsch, Wittelsbacherstraße, Germany) over a temperature range of $20-900{ }^{\circ} \mathrm{C}$ with a heating rate of $10{ }^{\circ} \mathrm{C}$ per minute under a constant flow of nitrogen gas [14].

\subsection{Chemical Composition of the Bioflocculant}

The total protein content of the purified bioflocculant was determined as described by Bradford [20] using bovine serum albumin (BSA) as the standard solution. The total sugar content was determined by phenol-sulphuric acid method described by Chaplin and Kennedy [21] using glucose as a standard solution. The uronic acid content of the bioflocculant was determined by carbazole method described by Bitter and Muir [22].

\subsection{Statistical Analysis}

All data were treated in replicates and the mean values were taken. Data were subjected to one-way analysis of variance (ANOVA) using MINITAB Student Release 12 statistical package. A significance level of $p<0.05$ was used.

\section{Results and Discussion}

\subsection{Bioflocculant Yield}

After fermenting $1 \mathrm{~L}$ of a mixed culture of Halomonas sp. Okoh and Micrococcus sp. Leo for 5 days, about $3.51 \mathrm{~g}$ of purified bioflocculant was recovered. Increase in the amount of bioflocculant recovered from the consortium compared to the individual strains (Halomonas sp. Okoh: $1.213 \mathrm{~g} / \mathrm{L}$; Micrococcus sp. Leo: $0.738 \mathrm{~g} / \mathrm{L}$ ) might be due to the synergistic effect observed when grown together. The higher bioflocculant yield observed with the consortium portends a reduction in production cost and as such, mixed culture fermentation may be preferred were the organisms act in synergy.

\subsection{Time Course Assay of Bioflocculant Production}

Optimum culture conditions that were used for bioflocculant production by individual strains (Halomonas sp. Okoh and Micrococcus sp. Leo) were adopted for culturing the consortium of the two strains. Figure 1 shows the time course assay of bioflocculant production. As expected, no cell growth was observed within the first $10 \mathrm{~h}$ of cultivation (lag phase). However, a steady increase in cell growth accompanied by a corresponding increase in flocculating activity was observed after this period. The 
stationary growth phase was attained after $120 \mathrm{~h}$ of cultivation. It was also observed that the flocculating activity ran parallel to cell growth, thus indicating a concomitant increase in bioflocculant production with cell growth. The flocculating activity of the bioflocculant reached its maximum flocculating peak of $63.2 \%$ at late stationary phase of $120 \mathrm{~h}$ and further increase in cultivation period resulted in a decrease in both flocculating activity and cell growth. This observation indicated that the production of bioflocculant was as a result of biosynthesis during the bacterial growth and not by cell autolysis [23]. The decrease in flocculating activity observed after $120 \mathrm{~h}$ could be attributed to the presence of bioflocculant-degrading enzymes produced by the microorganisms [4]. A similar observation was reported by Mabinya et al. [24] for the bioflocculant produced by Halomonas sp. Okoh which attained its maximum peak at $132 \mathrm{~h}$. On the contrary, the flocculating activity of the bioflocculant produced by Serratia fiacaria and Bacillus sp. F19 reached its maximal at early stationary phase of $72 \mathrm{~h}[25,26]$. The initial $\mathrm{pH}$ of the production medium was adjusted to 4 and then monitored at the regular intervals over the entire growth period. According to Salehizadeh and Shojaosadati [6], the $\mathrm{pH}$ of the production medium determines the electric charge of the cells and oxidation-reduction potential thus affecting nutrient absorption and enzymatic reactions. It was observed that there was a decrease in $\mathrm{pH}$ of the medium as cultivation time progresses. The decrease in $\mathrm{pH}$ of the medium may be due to the production of organic acids as a result of glucose metabolism since glucose was a component of the cultivation medium or the decrease in $\mathrm{pH}$ might be due to the presence of organic acids produced during metabolism by bacteria [7,27].

Figure 1. Time course for bioflocculant production by a mixed culture of Halomonas sp. Okoh and Micrococcus sp. Leo.

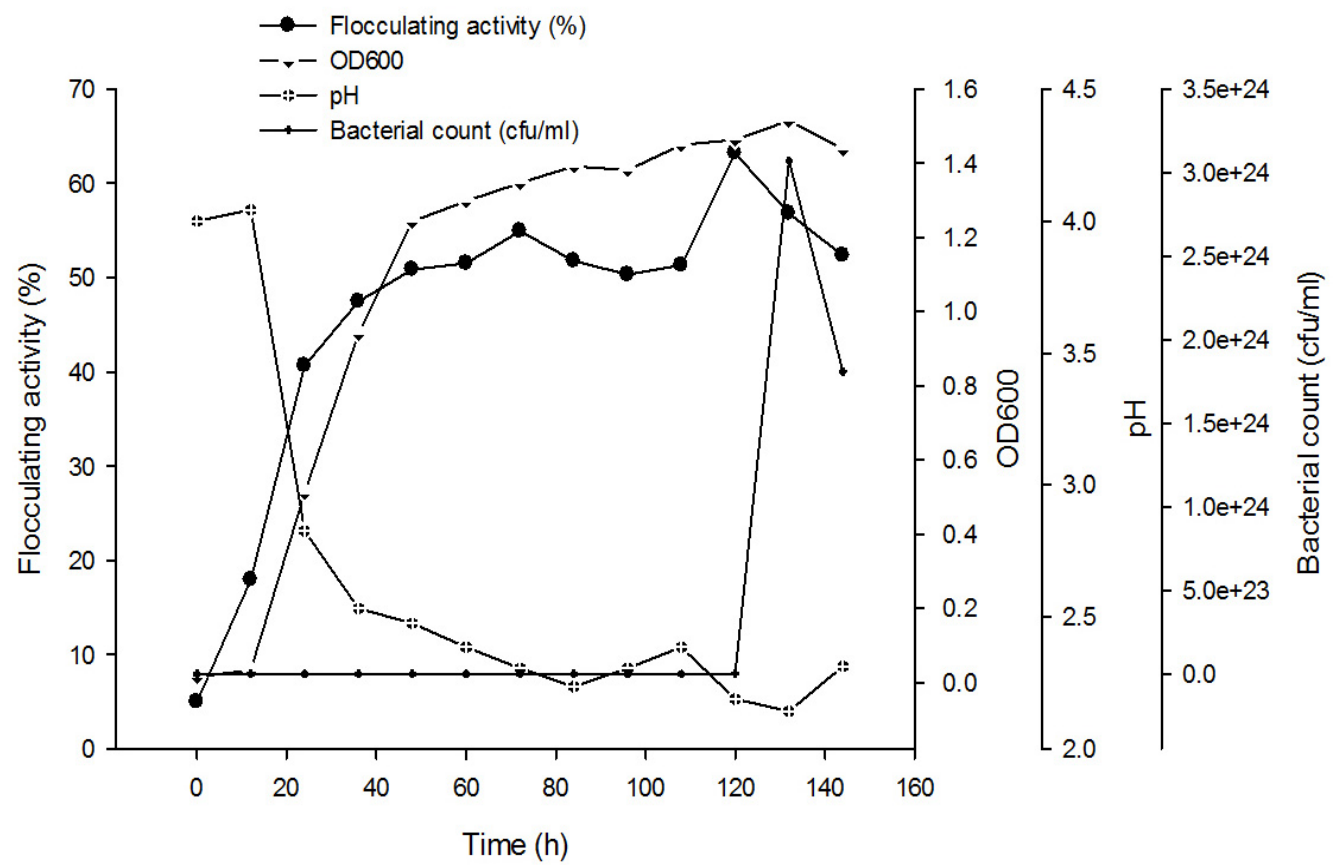

\subsection{Effect of Bioflocculant Dosage on Flocculating Activity of Purified Bioflocculant}

The appropriate bioflocculant concentration to be used for subsequent experiments was determined by investigating different bioflocculant concentrations ranging from $0.02-0.5 \mathrm{mg} / \mathrm{mL}$ as depicted 
in Figure 2. It was observed that the flocculating activity of the bioflocculant increased as the concentration increased. The optimum flocculating activity was obtained at $0.1 \mathrm{mg} / \mathrm{mL}$ and further increases in bioflocculant concentration resulted in a decline in the flocculating activity. According to the observation of Zufarzaana et al. [28], low dosage will not make bridging flocculation mechanism of the bioflocculant to be effective and high dosage will generate high viscosity which will inhibit the settling of suspended particles by restabilization of kaolin particles. When the bioflocculant molecules are excessively presence in the solution, they usually generate high viscosity, blocked the adsorption sites thereby reducing flocculating processing and flocs formation [14,25,28]. A similar observation was observed by Deng et al. [7] of the bioflocculant produced by Bacillus mucilaginosus that required a dosage of $0.1 \mathrm{mg} / \mathrm{mL}$ bioflocculant for optimum flocculating activity. On the contrary, the compound bioflocculant CBF-F26 produced by a mixed culture of Rhizobium radiobacter F2 and Bacillus sphaeicus $\mathrm{F} 6$ required a dosage of $12 \mathrm{mg} / \mathrm{L}$ for effective flocculating activity [14].

Figure 2. Effect of bioflocculant concentration on the flocculating activity of the bioflocculant produced by a consortium (Halomonas sp. Okoh and Micrococcus sp. Leo). Flocculating activities with different letters are significantly different $(p<0.05)$ from each other.

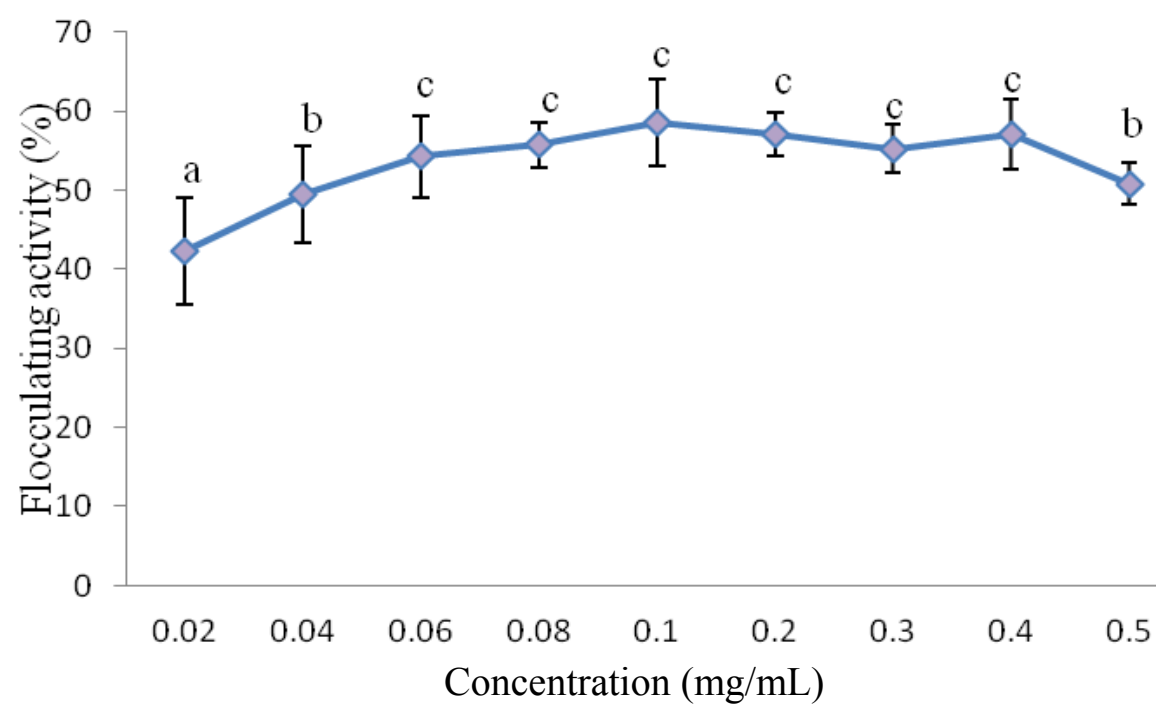

\subsection{Thermostability of the Purified Bioflocculant}

The relationship between temperature and flocculating activity of the bioflocculant was investigated (figure not shown). After heating $0.1 \mathrm{mg} / \mathrm{mL}$ solution of the purified bioflocculant at different temperatures ranging from $50-80^{\circ} \mathrm{C}$ for $30 \mathrm{~min}$, flocculating activity of the residual bioflocculant was measured at room temperature. There was a decrease in flocculating activity from $77.7 \%$ at $50{ }^{\circ} \mathrm{C}$ to approximately $70 \%$ at $80{ }^{\circ} \mathrm{C}$. The bioflocculant maintained and retained about $70 \%$ of its flocculating activity at $80{ }^{\circ} \mathrm{C}$ due to its structure which is mainly composed of polysaccharide. Li et al. [29] reported a decrease of only $9.2 \%$ in flocculating activity of the bioflocculant produced by Aeromonas sp. after being heated at $100{ }^{\circ} \mathrm{C}$ for $60 \mathrm{~min}$. Gong et al. [25] observed that the bioflocculant produced by Serratia ficaria could retain its flocculating activity after being heated at $100{ }^{\circ} \mathrm{C}$ for 15 min, mainly due to polysaccharide backbone. Li et al. [30] reported that the bioflocculant produced by 
Agrobacterium sp. M503 retained its flocculating activity up to $70{ }^{\circ} \mathrm{C}$ and a further increase in temperature up to $121{ }^{\circ} \mathrm{C}$ had no effect on flocculating activity. High thermostability property of a compound bioflocculant CBF-F26 was observed when the purified bioflocculant was heated over $100{ }^{\circ} \mathrm{C}$ for $30 \mathrm{~min}$. The residual flocculating activity of this bioflocculant was more than $90 \%$ [14].

\subsection{Effect of Cations on the Flocculating Activity of Purified Bioflocculant}

The role of cations on the flocculating activity of the bioflocculant produced by the consortium was investigated and the results are depicted in Figure 3. Of all the cations tested, the flocculating activity of the bioflocculant was enhanced albeit to varying degrees by $\mathrm{Ca}^{2+}(72 \%), \mathrm{Mn}^{2+}(59.8 \%)$ and $\mathrm{Al}^{3+}$ $(80 \%)$ and inhibited to different extents by $\mathrm{Li}^{+}(12.2 \%), \mathrm{Na}^{+}(18.8 \%), \mathrm{K}^{+}(7.4 \%), \mathrm{Mg}^{2+}(31.5 \%), \mathrm{Ba}^{2+}$ $(43.6 \%)$ and $\mathrm{Fe}^{3+}(36 \%)$. The role of cation is to neutralize and stabilize the negative charge of both functional groups of kaolin particle in solution and the bioflocculant [31,32]. Levy et al. [33] stated that the role of bivalent and trivalent cations is to increase the adsorption of bioflocculants on the suspended particles by decreasing the negative charge on both the polymer and the particle. Li et al. [4,34] also reported enhancement of flocculating activity of a bioflocculant produced by Bacillus licheniformis and Bacillus circulans in the presence of $\mathrm{Al}^{3+}, \mathrm{Fe}^{3+}$, and $\mathrm{Ca}^{2+}$. According to the investigation of Patil et al. [35] about the bioflocculant produced by a Bacillus substilis, the flocculating activity was stimulated in the presence of $\mathrm{Al}^{3+}$ and $\mathrm{Fe}^{3+}$. The compound bioflocculant produced by a mixed culture of Rhizobium radiobacter F2 and Bacillus sphaeicus F6, displayed flocculating activity of $97 \%$ when $\mathrm{Al}^{3+}$ was used as a coagulating aid [14].

Figure 3. Effect of cations on the flocculating activity of the bioflocculant produced by a consortium (Halomonas sp. Okoh and Micrococcus sp. Leo). Flocculating activities with different letters are significantly different $(p<0.05)$ from each other.

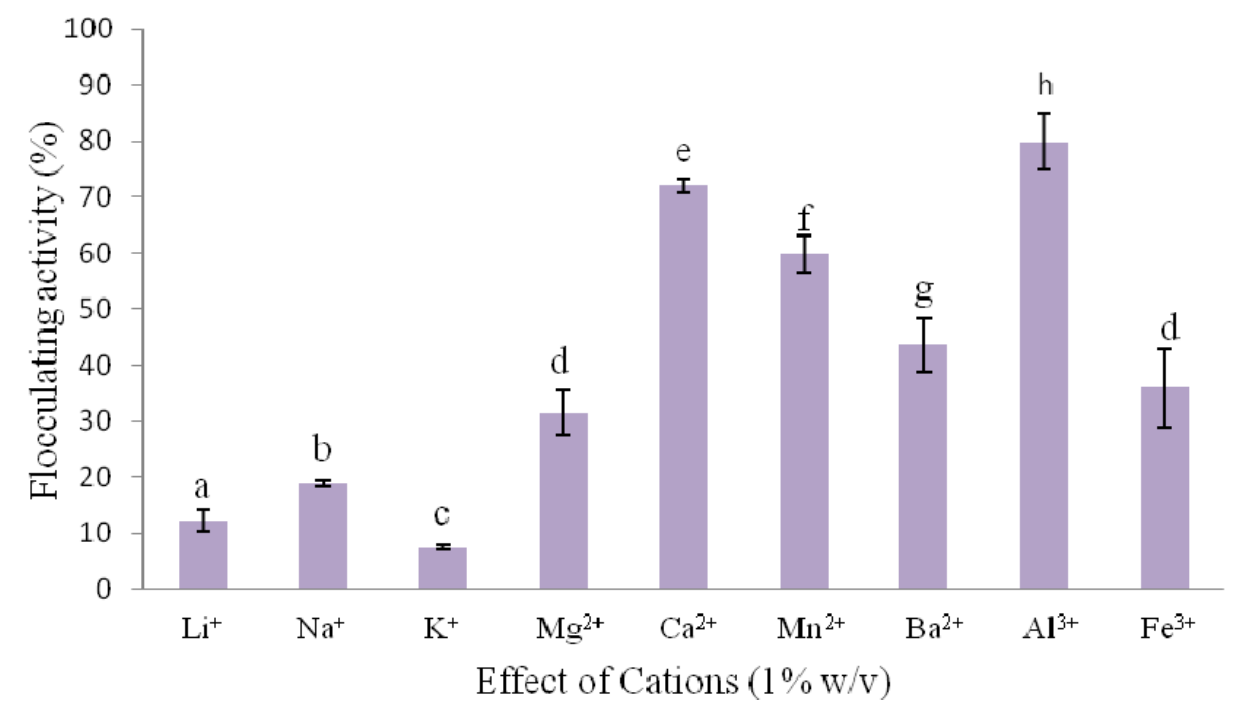

On the contrary, Cosa et al. [36] reported that the flocculating activity of the bioflocculant produced by Virgibacillus sp. Rob was greatly stimulated when $\mathrm{Fe}^{2+}$ was used as the cation. The bioflocculant produced by Chryserbacterium daeguense and Bacillus sp. F19 required no cation for its flocculation efficiency [26,37]. 


\subsection{Effect of $\mathrm{pH}$ on the Flocculating Activity of Purified Bioflocculant}

The effect of $\mathrm{pH}$ on the flocculating activity of the compound bioflocculant was investigated using bioflocculant dosage of $0.1 \mathrm{mg} / \mathrm{mL}$ at different $\mathrm{pH}$ values ranging from $2-11$. Figure 4 shows the results of the effect of $\mathrm{pH}$ on flocculating activity of the purified bioflocculant. It was observed that an increase in $\mathrm{pH}$ resulted into an increase in the flocculating activity of the produced bioflocculant. A sharp decreased in flocculating activity was recorded at $\mathrm{pH} 7$ with an immediate rise up to $\mathrm{pH} 8$ followed by a slight decrease and relative stability in $\mathrm{pH}$. It was observed that the bioflocculant produced flocculated well at a wide $\mathrm{pH}$ range of 2-10 with the maximum flocculating activity peak of $86 \%$ at $\mathrm{pH}$ 8. Yokoi et al. [38] stated that the $\mathrm{pH}$ of the solution plays an important role in flocculating efficiency of the bioflocculant. Wang et al. [14] stated that the $\mathrm{pH}$ affected stability of suspended particles and the formation of flocs. Yim et al. [39] reported that the bioflocculant p-KG03 produced by a marine dinoflagellate, Gyrodinium impudicum KG03 flocculated best under acidic conditions of $\mathrm{pH}$ 4. The optimum $\mathrm{pH}$ for flocculating activity of the biopolymer produced by Enterobacter cloacae WD7 was 6 [40]. The compound biopolymer CBF-F26 produced by a mixed culture of Rhizobium radiobacter F2 and Bacillus sphaeicus F6 had flocculating activity between pH 7-9 [14].

Figure 4. Effect of $\mathrm{pH}$ on the flocculating activity of the bioflocculant produced by a consortium (Halomonas sp. Okoh and Micrococcus sp. Leo). Flocculating activities with different letters are significantly different $(p<0.05)$ from each other.

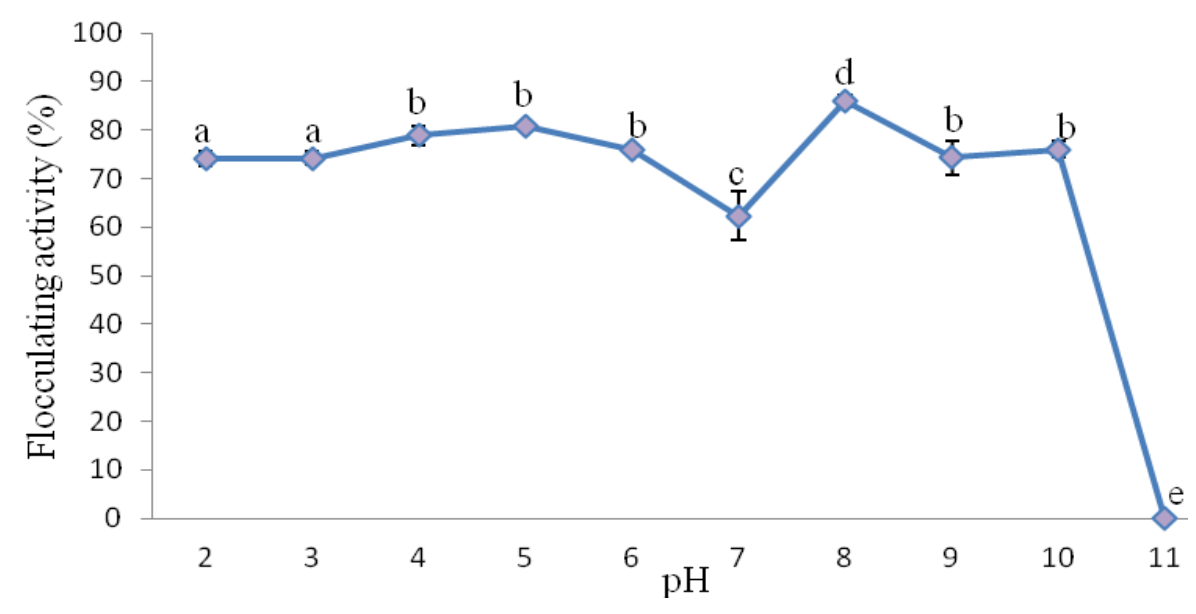

\subsection{Chemical Composition of the Purified Bioflocculant}

Chemical analysis showed that the purified bioflocculant was composed of $4.73 \%$ total protein content, $62.3 \%$ total sugar content and $25.7 \%$ uronic acid. Wang et al. [14] reported the purified bioflocculant CBF-F26 mainly composed of polysaccharide with monosaccharide units of rhamnose, mannose, glucose and galactose respectively in a 1.3:2.1:10.0:1.0 molar ratios.

\subsection{Thermogravimetric Property of the Purified Bioflocculant}

The thermogravimetric property analysis of the purified bioflocculant was used to elucidate its behaviours when subjected to heat. This enables us to understand its pyrolysis property when exposed to a very high temperature. From Figure 5, there was about $20 \%$ decrease in weight at $200{ }^{\circ} \mathrm{C}$ and 
about $29 \%$ loss of weight at $500{ }^{\circ} \mathrm{C}$. The first weight loss could be due to loss of moisture content in the bioflocculant [41]. Similarly, in the case of bioflocculant p-KG03 produced by a marine dinoflagellate Gyrodinium impudicum KG03 [39], the initial weight loss was observed between 40-230 ${ }^{\circ} \mathrm{C}$. Further decrease in weight loss of this bioflocculant was observed at about $310{ }^{\circ} \mathrm{C}$. Wang et al. [14] reported on a study conducted on a compound bioflocculant by a mixed culture of Rhizobium radiobacter F2 and Bacillus sphaeicus F6 where initial loss of about 10\% was observed between 20 and $150{ }^{\circ} \mathrm{C}$. Further decreased in weight of $40 \%$ was observed at $400{ }^{\circ} \mathrm{C}$ and there was a total loss of weight at $1,000{ }^{\circ} \mathrm{C}$.

Figure 5. Thermogravimetric analyses of the purified bioflocculant.

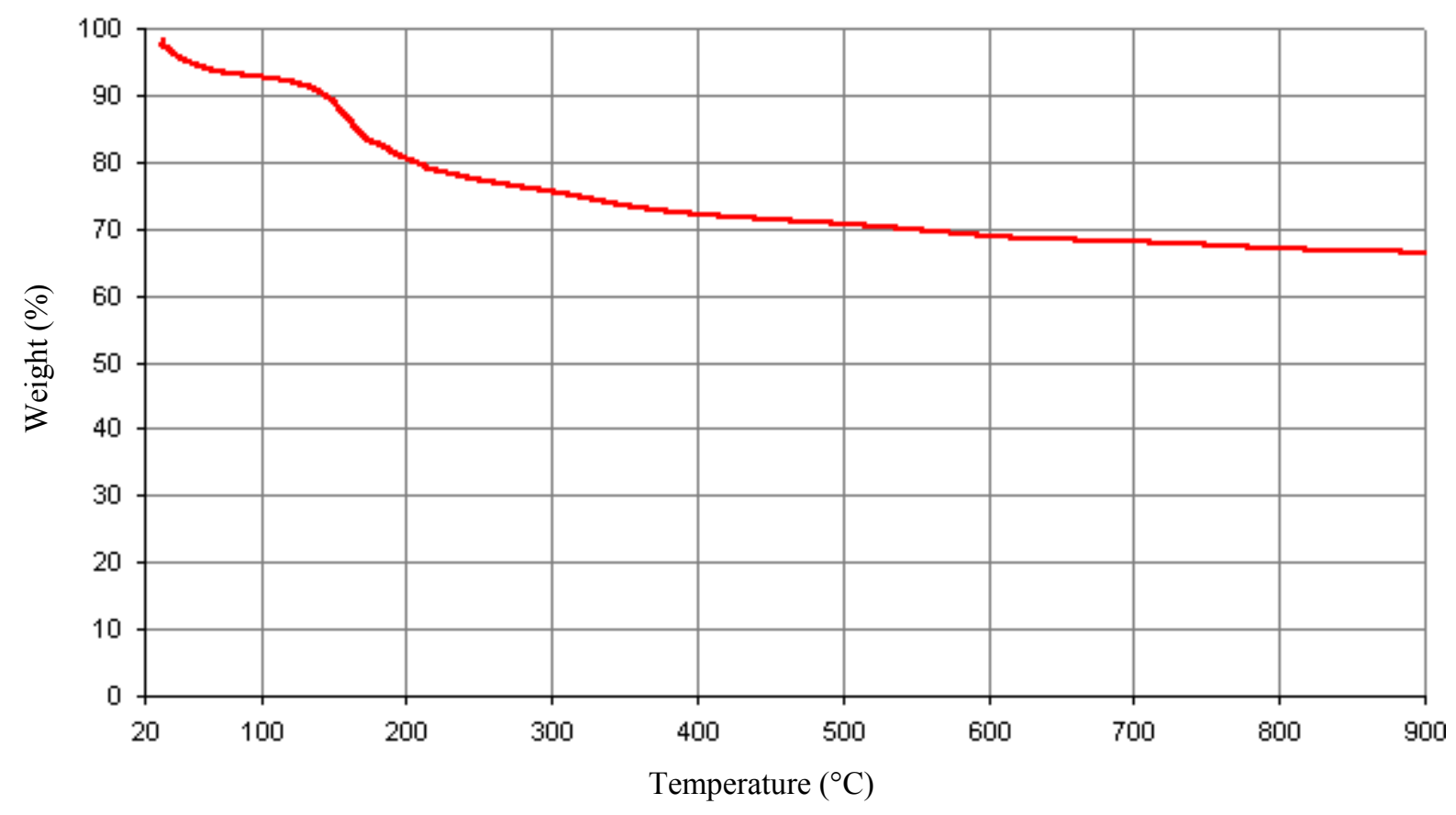

\subsection{Functional Groups Determination by FTIR}

The composition of the bioflocculants produced by different microorganisms differ [6]. The flocculating activity of the purified bioflocculant solely depends on the chemical structure which is related to the functional groups in the molecule. The Fourier-transform infrared (FTIR) spectrum analysis revealed the presence of different functional groups in the molecule. In Figure 6, the spectrum peak at 3,412 $\mathrm{cm}^{-1}$ showed the presence of $\mathrm{OH}$ group and $\mathrm{NH}_{2}$ group in the molecule [42]. The weak band noticed at $2,113 \mathrm{~cm}^{-1}$ indicated the presence of aliphatic bonds. The spectrum peak at $1,622 \mathrm{~cm}^{-1}$ is an indication of the presence of an amide group [9]. The vibration peak at $1,139 \mathrm{~cm}^{-1}$ corresponding to the $\mathrm{C}-\mathrm{O}$ stretching in alcohols and this further suggests the presence of $\mathrm{OH}$ group in the bioflocculant molecule [43]. The spectrum peaks in between $1,000-1,100 \mathrm{~cm}^{-1}$ suggested the presence of saccharide derivatives. 
Figure 6. Fourier transform infrared (FTIR) spectroscopy of the purified bioflocculant.

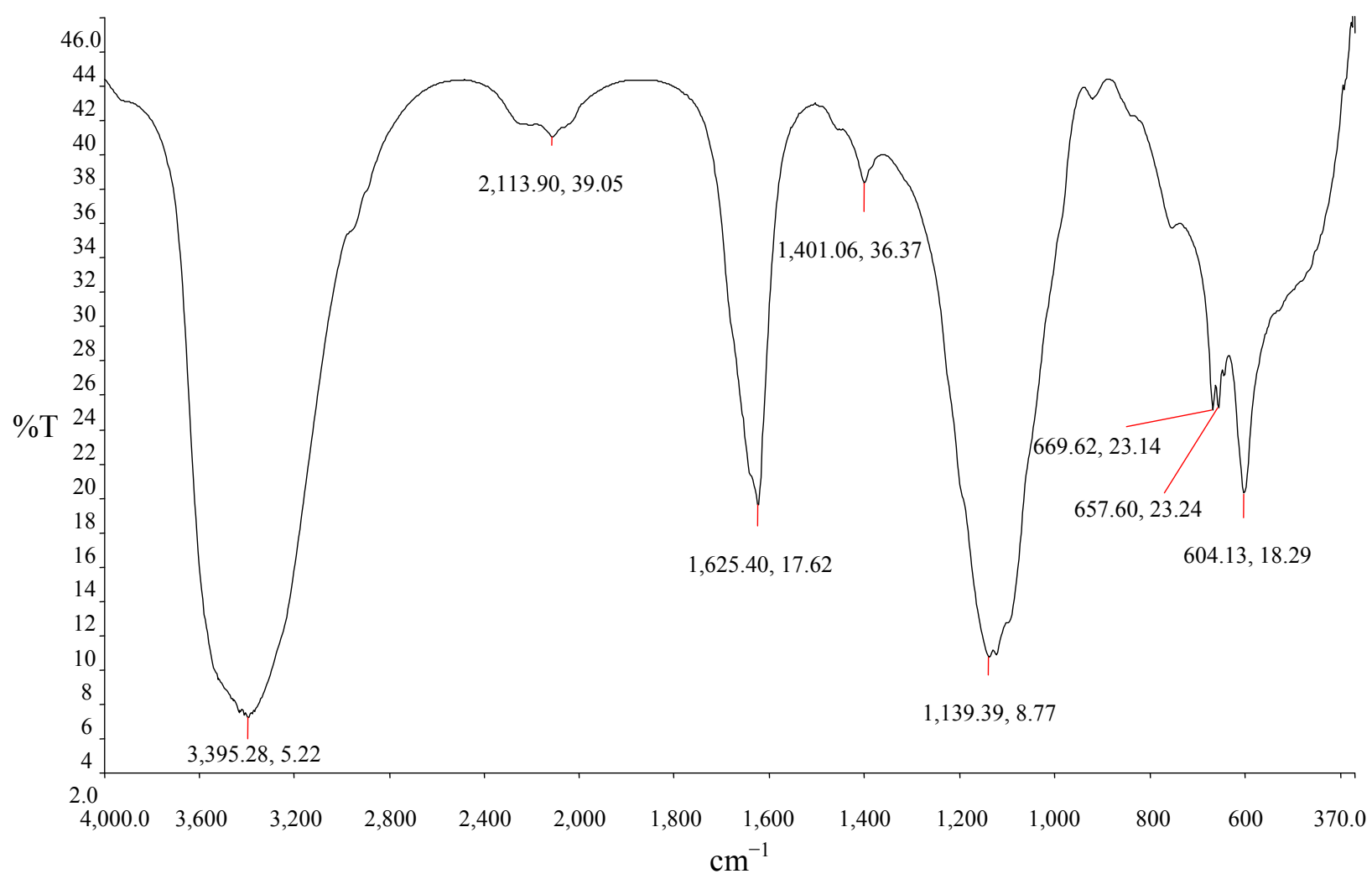

\section{Conclusions}

The flocculating efficiency and physicochemical properties of the compound bioflocculant produced by a mixed culture of Halomonas sp. Okoh and Micrococcus sp. Leo were investigated. The bioflocculant maintained wide $\mathrm{pH}$ range flocculating activity with a maximum peak of $86 \%$ at $\mathrm{pH} 8$. The glycoprotein bioflocculant possessed hydroxyl, carboxyl and amino groups in its molecule as the main functional groups which were responsible for the flocculation mechanism. Nonetheless, the high flocculation activity observed indicates prospects towards industrial applications, and in addition, further studies on process conditions are needed for the prospect of large-scale production.

\section{Acknowledgments}

We are grateful to the University of Fort Hare, Alice, South Africa and the Goven Mbeki Research Development Group for funding this study.

\section{Conflicts of Interest}

The authors declare no conflict of interest. 


\section{References}

1. Shih, I.L.; Van, Y.T.; Yeh, L.C.; Lin, H.G.; Chang, Y.N. Production of a biopolymer flocculant from Bacillus licheniformis and its flocculation properties. Bioresour. Technol. 2001, 78, 267-272.

2. Vanhoric, M.; Mones, W. Carcinogen of acrylamide. Carcinogensis 1983, 4, 1459-1463.

3. Dearfield, K.L.; Abernathy, C.O.; Ottley, M.S.; Brantner, J.H.; Hayes, P.F. Acrylamide: Its metabolism, developmental and reproductive effects, genotoxicity and carcinogenicity. Mutat. Res. 1988, 195, 45-77.

4. Li, Z.; Zhong, S.; Lei, H.; Chen, R.; Yu, Q.; Li, H. Production of a novel bioflocculant by Bacillus licheniformis X14 and its application to low temperature drinking water treatment. Biores. Technol. 2009, 100, 3650-3656.

5. Xia, S.Q.; Zhang, Z.Q.; Wang, X.J.; Yang, A.M.; Chen, L.; Zhao, J.F.; Didier, L.; Nicole, J.R. Production and characterization of a bioflocculant by Proteus mirabilis TJ-1. Bioresour. Technol. 2008, 99, 6520-6527.

6. Salehizadeh, H.; Shojaosadati, S.A. Extracellular biopolymeric flocculants: Recent trends and biotechnological importance. Biotechnol. Adv. 2001, 19, 371-385.

7. Deng, S.B.; Bai, R.B.; Hu, X.M.; Luo, Q. Characteristics of a bioflocculant produced by Bacillus mucilaginosus and its use in starch wastewater treatment. Appl. Microbiol. Biotechnol. 2003, 60, 588-593.

8. Li, Y.; He, N.; Guan, H.; Du, G.; Chen, J. A polygalacturonic acid bioflocculant REA-11 produced by Corynebacterium. glutamicum: A proposed biosynthetic pathway and experimental confirmation. Appl. Microbiol. Biotechnol. 2003, 63, 200-206.

9. Fujita, M.; Ike, M.; Tachibana, S.; Kitada, G.; Kim, S.; Inoue, Z. Characterization of a bioflocculant produced by Citrobacter. sp. TKF04 from acetic and propionic acids. J. Biosci. Bioeng. 2000, 89, 40-46.

10. Huang, M.S.; Shen, R.H.; Xia, J. Microbial flocculates: Productionand application on wastewater treatment. J. Shanghai Univ. (Nat. Sci.) 2001, 7, 244-248.

11. Zhou, X.; Wang, J.; Zhou, J.T. Studies on properties of a bioflocculant produced by Pseudomonas sp. GX4-1 in fishmeal wastewater. Res. Environ. Sci. 2003, 16, 31-34.

12. Ma, F.; Liu, J.L.; Li, S.G.; Yang, J.X.; Zhang, L.Q.; Wu, B.; Zhu, Y.B. Development of complex microbial flocculant. China Water Wastewater 2003, 19, 1-4.

13. Zhu, Y.B.; Feng, M.; Yang, J.X. Screening of complex bioflocculant producing bacterium and their flocculating mechanism. J. Harbin Inst. Technol. 2004, 36, 759-762.

14. Wang, L.; Ma, F.; Qu, Y.; Sun, D.; Li, A.; Guo, J.; Yu, B. Characterization of a compound bioflocculant produced by mixed culture of Rhizobium. radiobacter F2 and Bacillus sphaeicus F6. W. J. Microbiol. Biotechnol. 2011, 27, 2559-2565.

15. Zhang, Z.; Lin, B.; Xia, S.; Wang, X.; Yang, A. Production and application of a novel bioflocculant by multi-microorganism consortia using brewery wastewater as carbon source. J. Environ. Sci. 2007, 19, 667-673. 
16. Kurane, R.; Hatamochi, K.; Kakuno, T.; Kiyohara, M.; Hirano, M.; Taniguchi, Y. Production of a bioflocculant by Rhodococcus erythropolis S-1 grown on alcohols. Biosci. Biotechnol. Biochem. 1994, 2, 428-429.

17. Wang, Y.; Gao, B.Y.; Yue, Q.Y.; Wei, J.C.; Zhou, W.Z.; Gu, R. Color removal from textile industry wastewater using composite flocculants. Environ. Technol. 2010, 28, 629-637.

18. Xiong, Y.; Wang, Y.; Yu, Y.; Li, Q.; Wang, H.; Chen, R.; He, N. Production and characterization of a novel bioflocculant from Bacillus licheniformis. Appl. Environ. Microbiol. 2010, 76, 2778-2782.

19. He, J.; Zou, J.; Shao, Z.; Zhang, J. Characteristics and flocculating mechanism of a novel bioflocculant HBF-3 produced by deep-sea bacterium mutant Halomona. sp. V3a. W. J. Microbiol. Biotechnol. 2010, 26, 1135-1141.

20. Bradford, M.M. A rapid and sensitive method for the quantitation of microgram quantities of protein utilizing the principle of protein-dye binding. Anal. Biochem. 1976, 72, 248-254.

21. Chaplin, M.F.; Kennedy, J.F. Carbohydrate Analysis, 2nd ed.; Oxford University Press: New York, NY, USA, 1994.

22. Bitter, T.; Muir, H.M. A modified uronic acid carbazole reaction. Analyt. Biochem. 1962, 4, 330-334.

23. Gao, J.; Bao, H.Y.; Xin, M.X.; Liu, Y.X.; Li, Q.; Zhang, Y.F. Characterization of a bioflocculant from a newly isolated Vagococcus. sp. W31. J. Zhejiang Univ. Sci. B. 2006, 7, 186-192.

24. Mabinya, L.V.; Cosa, S.; Mkwetshana, N.; Okoh, A.I. Halomonas. sp. OKOH-A marine bacterium isolated from the bottom sediment of Algoa Bay-Produces a polysaccharide bioflocculant: Partial characterization and biochemical analysis of its properties. Molecules 2011, 16, 4358-4370.

25. Gong, W.; Wang, S.; Sun, X.; Liu, X.; Yue, Q.; Gao, B. Bioflocculant production by culture of Serratia. ficaria and its application in wastewater treatment. Bioresour. Technol. 2008, 99, $4668-4674$.

26. Zheng, Y.; Ye, Z.; Fang, X.; Li, Y.; Cia, W. Production and characteristics of a bioflocculant produced by Bacillus sp. F19. Biosour. Technol. 2008, 99, 7686-7691.

27. Lu, W.Y.; Zhang, T.; Zhang, D.Y.; Li, C.H.; Wen, J.P.; Du, L.X. A novel bioflocculant produced by Enterobacter aerogenes and its use in defaecating the trona suspension. Biochem. Eng. J. 2005, $27,1-7$.

28. Zufarzaana, Z.; Ahmad, Z.A.; Zulkifli, H.S.; Mohd, K.Y. Cation dependence, pH tolerance, and dosage requirement of a bioflocculant produced by Bacillus spp. UPMB13: Flocculation performance optimization through Kaolin assays. Sci. World. J. 2012, doi:10.1100/2012/495659.

29. Li, X.M.; Yang, Q.; Huang, K.; Zheng, G.M.; Xiao, D.X.; Liu, J.J.; Long, W.F. Screening and characterization of a bioflocculant produced by Aeromonas. sp. Biomed. Environ. Sci. 2007, 20, 274-278.

30. Li, Q.; Liu, H.L.; Qi, Q.; Wang, F.; Zhang, Y. Isolation and characterization of temperature and alkaline stable bioflocculant from Agrobacterium. sp. M503. New Biotechnol. 2010, 27, 789-794.

31. Salehizadeh, H.; Shojaosadati, S.A. Isolation and characterization of a bioflocculant produced by Bacillus firmus. Biotechnol. Lett. 2002, 24, 35-40.

32. Wu, J.Y.; Ye, H.F. Characterization and flocculanting properties of an extracelluar biopolymer produced from a Bacillus subtilis DYU1 isolate. Process. Biochem. 2007, 42, 1114-1123. 
33. Levy, N.; Magdassi, S.; Bar-Or, Y. Physico-chemical aspects in flocculation of bentonite suspensions by a cyanobacterial bioflocculant. Water Res. 1992, 26, 249-254.

34. Li, Z.; Chen, R.; Lei, H.; Shan, Z.; Bai, T.; Yu, Q.; Li, H. Characaterization and flocculating properties of a novel bioflocculant produced by Bacillus circulans. World J. Microbiol. Biotechnol. 2009b, 25, 745-752.

35. Patil, S.V.; Bathe, G.A.; Patil, A.V.; Patil, R.H.; Salunkea, R. Production of bioflocculant exopolysaccharide by Bacillus subtilis. Adv. Biotechnol. 2009, 58, 15-16.

36. Cosa, S.; Mabinya, L.V.; Olaniran, A.O.; Okoh, O.O.; Okoh, A.I. Bioflocculant production by Virgibacillus. sp. Rob Isolated from the bottom sediment of Algoa Bay in the Eastern Cape, South Africa. Molecules 2011, 16, 2431-2442.

37. Liu, W.; Wang, K.; Li, B.; Yuan, H.; Yang, J. Production and characterization of an intracellular biofloculant by Chryseobacterium daeguense W6 cultured in low nutrition medium. Bioresour. Technol. 2010, 101, 1044-1048.

38. Yokoi, H.; Natsuda, O.; Hirose, J.; Hayashi, S.; Takasaki, Y. Characteristics of a biopolymer flocculant produced by Bacillus sp. PY-90. J. Ferment. Bioeng. 1995, 79, 378-380.

39. Yim, J.H.; Kim, S.J.; Ahn, S.H.; Lee, H.K. Characterization of a novel bioflocculant, p-KG03, from a marine dinoflagellate, Gyrodinium impudicum KG03. Bioresour. Technol. 2007, 98, 361-367.

40. Prasertsan, P.; Dermlim, W.; Doelle, H.; Kennedy, J.F. Screening, characterization and flocculating property of carbohydrate polymer from newly isolated Enterobacter cloacae WD7. Carbohydr. Polym. 2006, 66, 289-297.

41. Kumar, C.G.; Anand, S.K. Significance of microbial biofilms in food industry: A review. Int. J. Food Microbiol. 1998, 42, 9-27.

42. Desouky, A.M.; Haleem, A.E.; Roda, F.T.; Thourya, M.; Sidra, M.; Fatima, H. Isolation and characterization of extracellular bioflocculants produced by bacteria isolated from Quatari Ecosystems. Pol. J. Microbiol. 2008, 57, 231-239.

43. Deng, S.B.; Yu, G.; Ting, Y.P. Production of a bioflocculant by Aspergillus parasiticus and its application in dye removal. Colloids Surf. B. Biointerfaces 2005, 44, 179-186.

(C) 2013 by the authors; licensee MDPI, Basel, Switzerland. This article is an open access article distributed under the terms and conditions of the Creative Commons Attribution license (http://creativecommons.org/licenses/by/3.0/). 